\title{
Zapadalność i umieralność z powodu odry na Ukrainie. Implikacje dla działań profilaktycznych
}

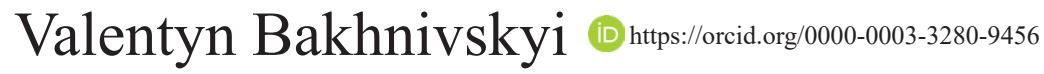

Lek. med., doktorant Wydziału Ekonomii i Stosunków Międzynarodowych na Uniwersytecie Ekonomicznym w Krakowie, Miejski Szpital Specjalistyczny im. S. Żeromskiego w Krakowie, radny Winnickiej Rady Rejonowej (Ukraina)

Adres do korespondencji: b.valik26770377@gmail.com

\section{Abstract}

\section{Incidence and mortality from measles in Ukraine - implication for preventive action}

According to the definition of the World Bank and World Health Organization health of the population is one of the main factors for the development of the economy and the social well-being of each country. Several positive changes have recently occurred in the health care field of Ukraine. However, despite of that the state of health of this country's population is currently assessed as insufficient. Since independence in 1991 Ukraine has not reached such a level of measles virus elimination as the Member States of the European Union. The aim of this article is to analyze the level of morbidity and mortality due to measles and the state of measles vaccination in Ukraine. In 2018, 53219 measles cases were registered in Ukraine (incidence rate $-125,47$ per 100,000). The situation compared to the previous year deteriorated significantly and was 12-fold. In 2018, 16 people died of measles -12 children and 4 adults. The status of inoculation of children under one year of age was $91 \%$, which was less by $2 \%$ compared to 2017 , but twice as much as in 2016, where only 46\% children aged less than 1 year were vaccinated. Indicators of the epidemiological situation in Ukraine in 2018 deteriorated to a large extent compared to 2017. Based on the current trends in measles vaccination and the frequency of its occurrence, it could be argued that the elimination of measles is very much at risk due to both migration and the rapid development of anti-vaccine movements.

\section{Key words: measles, epidemiology, prophylaxis, prevention, vaccination, Ukraine}

Stowa kluczowe: odra, epidemiologia, profilaktykka, szczepienia, Ukraina

\section{Wprowadzenie}

Zdrowie ludności jest powszechnie traktowane jako jedna z najwyższych wartości w życiu każdego człowieka. Jest podstawowym i bodaj często najbardziej niezbędnym składnikiem, zarówno jednostkowego dobrostanu, jak i społeczno-gospodarczego rozwoju każdego kraju [1]. Choroby zakaźne od zawsze stanowiły niebezpieczeństwo, bezpośrednio zagrażając życiu człowieka, a także jego zdrowiu, głównie z powodu wywoływanych przez nie powikłań, prowadzących często do trwałej niepełnosprawności. Odra jest wysoce zakaźną chorobą wirusową. Wprawdzie w 2002 roku nie zarejestrowano żadnego przypadku w Ameryce Północnej i w niektórych krajach Europy [2], ale mimo to nadal stanowi częstą przyczynę zachorowań i śmierci wśród małych dzieci na całym świecie, zwłaszcza w krajach rozwijających się, pomimo dostępności bezpiecznej i skutecznie działającej szczepionki.

Ukraina jest państwem leżącym we wschodniej części Europy, liczącym 42 miliony obywateli, które było częścią Związku Radzieckiego do roku 1991. Podobnie jak w innych republikach Związku Radzieckiego szczepionka przeciwko odrze została wprowadzona na Ukrainie w roku 1968 jednodawkowo - dla dzieci do 15. miesiąca życia, ale epidemie odry występowały nadal co 3-4 lata. Dwie dawki szczepionki wprowadzono w 1986 roku pierwszą dla dzieci w wieku 15 miesięcy, drugą dla dzieci w wieku 6 lat. Mimo to epidemie odry wystapiły w roku 1993 (zapadalność 34,1 przypadków na 100000 osób), w 1996 (zapadalność 16,8/100 000) oraz w 2001 (zapadalność 34,3/100 000). Jednolita szczepionka prze- 
ciw odrze, wykorzystująca szczep Leningrad-16, została wyprodukowana w byłym Związku Radzieckim i używano jej na Ukrainie do roku 1993. W następnych latach stosowano ją wraz z także monowalentną szczepionką przeciw odrze, dostarczaną przez UNICEF. Później została wprowadzona atenuowana szczepionka MMR przeciw odrze, śwince i różyczce.

Od 2002 roku roku schemat szczepień przeciw odrze na Ukrainie obejmuje podanie pierwszej (podstawowej) dawki do 12. miesiąca życia oraz dawki przypominającej w 6. roku życia. Stosuje się żywą, atenuowaną, skojarzoną szczepionkę przeciw odrze, śwince i różyczce (MMR) podawaną podskórnie.

W latach 2005-2006 odnotowano ponad 50 tys. przypadków zachorowań na odrę, z tego więcej niż $60 \%$ u osób w grupie wiekowej 15-29 lat [3, 4].

Obecnie na Ukrainie, mimo pewnej poprawy sytuacji społeczno-politycznej i wielu pozytywnych zmian, do których doszło w ostatnim czasie w organizacji opieki medycznej (na przykład: wprowadzenie standardów oceny technologii medycznych, protokołów klinicznych, reformy podstawowej opieki zdrowotnej, reformy pogotowia $\mathrm{z}$ podziałem na wezwania alarmowe i natychmiastowe), stan zdrowia ludności tego kraju jest oceniany jako niedostateczny [5-7]. Jednym z podstawowych problemów aktualnej sytuacji epidemiologicznej w odniesieniu do chorób zakaźnych jest poziom profilaktyki, czyli nieodpowiednio zdefiniowane potrzeby populacji w zakresie szczepień, również szczepień przeciwko odrze. Sytuację bardzo pogarsza wpływ szybko rozwijających się ruchów antyszczepionkowych. Ponadto poważne zagrożenie stanowi zwiększający się poważnie w ostatnim okresie ruch ludności: turystyczny, handlowy, przesiedleńczy, wywołany czynnikami ekonomicznymigłównie w poszukiwaniu pracy. Zagrożenie, jakim jest szybkie rozpowszechnianie się odry, jest alarmującym sygnałem dla służb ochrony zdrowia wszystkich krajów, a także Biur Regionalnych Światowej Organizacji Zdrowia (WHO), zmuszającym te instytucje do bardziej intensywnego zaangażowania się w tworzenie nowych programów w celu eliminacji odry, a także przede wszystkim w ich realizację, jak również - być może - konieczności zrewidowania dotychczasowych działań.

\section{Inicjatywy WHO}

\subsection{Założenia ogólne}

WHO jest wiodącą instytucją odpowiedzialną za koordynację działań w zakresie szczepień i nadzoru, wspierającą wszystkie kraje w działaniach zmierzających do eliminacji rozprzestrzeniania się chorób. W wyniku wdrażania w wielu krajach na całym świecie licznych zaleceń WHO osiągnięto znaczne zmniejszenie liczby zachorowań na odrę oraz liczby zgonów z powodu tej choroby. Nie ulega wątpliwości, że stało się to w wyniku zwiększania zasięgu stosowania szczepionki przeciwko odrze zawierającej dwie dawki. Jedną z inicjatyw WHO zmierzających do zmniejszenia liczby przypadków zachorowań na odrę i różyczkę jest tak zwany Globalny Plan (dalej - Plan) działania dotyczący szczepionek przeciwko tym chorobom, zatwierdzony przez WHO i prowadzący do eliminacji odry w co najmniej pięciu $\mathrm{z}$ sześciu regionów ${ }^{1}$ Światowej Organizacji Zdrowia do 2020 roku [8]. Jest to trudny i złożony cel, ponieważ kontrola odry polega na ochronie przed zakażeniem za pomocą szczepień przeciwko tej chorobie, a to oznacza, że odpowiednie służby opieki zdrowotnej muszą być w stanie dotrzeć do każdego, kto jest potencjalnie zagrożony zarażeniem wirusem odry. Globalna kontrola odry okazała się bardzo skuteczna. Oszacowano, że na świecie liczba zgonów spadła z 535300 w 2000 do 110000 zgonów z powodu odry w 2017 roku, co stanowi zmniejszenie tej liczby o $80 \%$, głównie wśród dzieci poniżej 5. roku życia [8]. Warto odnotować, że w roku 2010 WHO zwołała ekspercki komitet doradczy w celu oceny możliwości eliminacji odry. Uczestnicy panelu stwierdzili, że eradykacja, czyli ogólnoświatowe przerwanie transmisji wirusa odry w obecności systemu nadzoru, który został sprawdzony pod względem skuteczności, jest realnie możliwa zarówno pod względem biologicznym, technicznym, jak i operacyjnym. Natomiast termin ,eliminacja” oznacza brak endemicznego wirusa odry na określonym obszarze geograficznym przez ponad 12 miesięcy w obecności dobrze działającego systemu nadzoru [9]. W fazie eliminacji odry konieczne jest ścisłe monitorowanie zarówno przypadków podejrzeń zachorowania na odrę oraz występowania przypadków wtórnych w ogniskach, jak i kontynuowanie genetycznych badań szczepów wirusa odry [10]. Plan działania WHO na lata 2012-2020 określił cel jako wyeliminowanie odry w co najmniej pięciu regionach WHO. Wszystkie regiony ustanowiły kryteria w celu sprawdzenia postępów w eliminacji odry do 2020 roku [11]. W ślad za tym państwa członkowskie we wszystkich sześciu regionach ustaliły cele $w$ zakresie eliminacji odry do roku 2020 lub wcześniej [12]. Uznając i planując eradykację odry, przyjęto, że stanie się to pod warunkiem osiągnięcia 95-procentowego poziomu zaszczepienia populacji.

\subsection{Globalny Plan WHO 2012-2020}

Plan WHO na lata 2012-2020 zawiera ogólny kontekst i ocenę aktualnego stanu zdrowia w odniesieniu do krajowego, regionalnego i globalnego zarządzania odrą i różyczką. Określa on zasady, które stanowią podstawę wszystkich działań kontrolnych w zakresie odry i różyczki, w tym odpowiedzialność władz kraju, wzmocnienie wagi szczepień i systemów opieki zdrowotnej, zapewnienie powiązań z innymi interwencjami zdrowotnymi oraz zagwarantowanie równości w immunizacji poprzez dotarcie ze szczepionką do każdego dziecka. Biorąc pod uwagę dotychczasowy postęp, plan zawiera listę krajów priorytetowych, które wymagają dodatkowego wsparcia, aby osiągnąć cele regionalne i globalne. Efektywne zarządzanie i koordynacja w Planie zostały zapewnione poprzez [8]:

1. Jasno określone role i obowiązki dla krajów i partnerów (np. organizacje pozarządowe) w przeprowadzeniu szczepień. 
2. Jasno określone wskaźniki, proces monitorowania i ocenę.

3. Regularną i elastyczną koordynację obejmującą cotygodniowe raportowanie $\mathrm{z}$ regionów i kluczowych (priorytetowych) krajów, w tym - planowane dwa razy w roku spotkania zainteresowanych stron.

4. Usprawnienie mechanizmu sprawozdawczego dotyczącego rocznych postępów związanych z wdrażaniem.

5. Planowanie oparte na danych statystycznych i budżetowaniu.

W Planie przeanalizowano również kluczowe elementy dotyczące kontroli i eliminacji odry oraz różyczki, takie jak:

- ryzyko finansowe, czyli ograniczenia zasobów, które stanowią główne wyzwanie;

- gęstość zaludnienia i wysoce mobilne populacje;

- słabe systemy immunizacji;

- natychmiastowe reagowanie i walka z błędnymi wyobrażeniami.

Podstawą budowania mocnego systemu opieki zdrowotnej zapewniającego skuteczną immunizację jest trwałe finansowanie w postaci funduszy celowych. Taki system pomaga w kontroli i eliminacji wirusa odry, co w końcowym rozrachunku doprowadza do osiągnięcia celów zawartych w Planie Strategicznym WHO na 2020 rok. Problemem są miejsca o dużej gęstości zaludnienia i procesy migracyjne, z powodu których wysoce zaraźliwa natura odry sprawia, że kontrola i eliminacja wirusa są bardzo trudne. Taką sytuację mamy w Indiach, które mają obecnie największą szacowaną liczbę przypadków odry i zgonów z powodu stosunkowo niskiej skali szczepień, niepełnej realizacji strategii dwóch dawek szczepionki przeciwko odrze i populacji o dużej gęstości. Podobnie duża liczba zachorowań występuje na Ukrainie, gdzie procesy migracyjne $\mathrm{z}$ powodu problemów ekonomicznych są obecnie bardzo intensywne. Migracji sprzyja również zniesienie wiz oraz praca za granicą - w Polsce, Portugalii, we Włoszech. W związku z tym wirus może zostać zawieziony i rozprzestrzeniony w innych państwach. Uwzględniając obecny stan zapadalności na odrę, autor artykułu zauważa na Ukrainie pilną potrzebę przygotowania nowego planu określającego strategie działań w dłuższej perspektywie czasowej. Należy sobie zdawać sprawę z powagi sytuacji i trudności, które występują w czasie tworzenia skutecznych systemów kontroli i eliminacji wirusa odry.

Plan Strategiczny WHO 2012-2020 oferuje rozwiązania tych problemów, omawia rolę i obowiązki interesariuszy oraz dostarcza wskaźników do monitorowania i oceny postępów krajowych, regionalnych i globalnych w realizacji nakreślonych wizji i postawionych celów.

\subsection{Sytuacja epidemiologiczna odry na świecie}

Zgodnie z danymi WHO w roku 2018 w porównaniu z rokiem 2017 liczba zachorowań na odrę we wszystkich regionach WHO wzrosła o 67\%. Duży wzrost odnotowano w regionie Ameryk: z 850 zarejestrowanych chorych w 2017 do 16966 w 2018 roku. W regionie europejskim według danych WHO liczba chorych wzrosła z 25465 do 89 578. Najwięcej zachorowań na odrę w 2018 roku w Europejskim Regionie WHO odnotowano na Ukrainie - 53 219, w Serbii - 5076, we Francji - 2913, we Włoszech - 2517 i w Rumunii - 1087 [3].

W 2017 roku we Włoszech odnotowano największą liczbę zachorowań na odrę w ciągu ostatnich lat. Zarejestrowano 5404 przypadki [4]. W związku z tym w niektórych regionach Włoch władze podjęły decyzję, że nieszczepione dzieci nie mogą uczęszczać do placówek zapewniających opiekę dzienną (żłobki, przedszkola, świetlice) [13, 14].

W 2011 roku Kanada doświadczyła największego wybuchu odry od czasu eliminacji tego wirusa w Amerykańskim Regionie WHO. Było to związane z przeniesieniem wirusa do Quebecu z Francji. Zagrożenie zostało opanowane przez służby sanitarne w ciągu 12 miesięcy w ten sposób, aby endemiczna transmisja nie została przywrócona [12]. Doświadczenia związane z tą i kilkoma innymi epidemiami podkreśliły znaczenie osiągnięcia poziomu wyszczepienia ponad $95 \%$ populacji. Ponieważ obie Ameryki i Zachodni Pacyfik osiągnęły postęp i utrzymały odpowiedni poziom eliminacji odry, pojawiły się charakterystyczne, powszechne wzorce epidemiologiczne w niezwykle różnorodnych populacjach, potwierdzające przewidywania teoretyczne. Te wspólne cechy, które wydają się równoznaczne $\mathrm{z}$ eliminacją, stanowią przykład, który poszczególne kraje dążące do eliminacji mogą stosować, aby ocenić własne postępy.

\section{Materiał i metody}

Artykuł oparto na analizie danych aktualnej sytuacji epidemiologicznej odry na Ukrainie i stanu uodpornienia populacji ukraińskiej w roku 2018, którą przeprowadzono na podstawie danych pochodzących ze źródeł statystycznych Światowej Organizacji Zdrowia [15], Ministerstwa Zdrowia Ukrainy oraz Centrum Zdrowia Publicznego (przy Ministerstwie Zdrowia Ukrainy) - jednostki odpowiedzialnej za nadzór nad chorobami, w tym chorobami zakaźnymi na terenie całego kraju. Analizę opisową przeprowadzono na podstawie danych dotyczących grup wiekowych, terminów wystąpienia choroby, zasięgu szczepieniami oraz rejestracji według obwodu zamieszkania. Wykorzystano następujące techniki badawcze: przegląd krajowej i zagranicznej literatury fachowej, interpretację aktualnej dokumentacji wyżej wymienionych instytucji, przegląd przypadków opisanych w literaturze, metody wnioskowania, takie jak dedukcja i indukcja, metodę syntezy wyników badań i wnioskowania.

\section{Wyniki badań}

\section{Sytuacja epidemiologiczna odry na Ukrainie}

W prawie całej Europie wzrasta liczba zachorowań na odrę, ale wśród krajów, w których przyrost nowych przypadków jest największy, na czołowym miejscu znajduje się Ukraina [16]. Jest ich tak dużo, że są podstawy, by twierdzić, że w tym kraju trwa epidemia odry - jednej z najbardziej zakaźnych chorób znanych na świecie [17]. 
Nie ma lekarstwa na odrę, jedyną skuteczną metodą zapobiegania tej chorobie są szczepienia. Epidemie odry są cykliczne i pojawiają się co 5-6 lat. Jak wcześniej wspomniano, główną przyczyną wybuchów epidemii jest niski poziom immunizacji. W 2016 roku mniej niż połowa ukraińskich dzieci (46\% populacji) została zaszczepiona przeciwko odrze [18, 19]. Od września 2017 roku, zgodnie z decyzją Ministerstwa Zdrowia Ukrainy, aby zareagować na sytuację związaną z niskim poziomem wyszczepień przeciwko odrze, wprowadzono intensywne działania w zakresie szczepień w celu ochrony jak największej liczby dzieci i zapobiegania rozwojowi epidemii. W 2017 roku poziom wyszczepienia przeciwko odrze wzrósł dwukrotnie i wyniósł 93\% [19] (Tabela I, Wykres 1).

W Europejskim Regionie WHO w 2018 roku z powodu odry zmarły 72 osoby, z których 16 na Ukrainie (12 dzieci i 4 dorosłych) [14]. Sytuacja epidemiologiczna odry w 2018 roku w porównaniu z rokiem poprzednim charakteryzowała się znacznym wzrostem liczby zachorowań (12-krotny wzrost). Na Ukrainie w 2018 roku odnotowano 53219 przypadków zachorowań na odrę (zapadalność wynosiła 125,47 na 100 tys. ludności), a w 2017 zarejestrowano 4782 przypadki (zapadalność 11,23 na 100 tys. ludności) - Tabela II [19, 20].

Na Wykresie 2 można zaobserwować wspomnianą wyżej cykliczność. Pierwszy wzrost zachorowalności na odrę na Ukrainie był zarejestrowany w 2001, następny w 2005, potem w 2012 i 2018 roku. Eliminacja odry wymaga bardzo wysokiego poziomu odporności populacji. Grupy wiekowe dotknięte epidemią w latach 2005-2006 to te same grupy urodzeniowe, które były szczególnie dotknięte podczas epidemii odry w latach 2000-2001, co

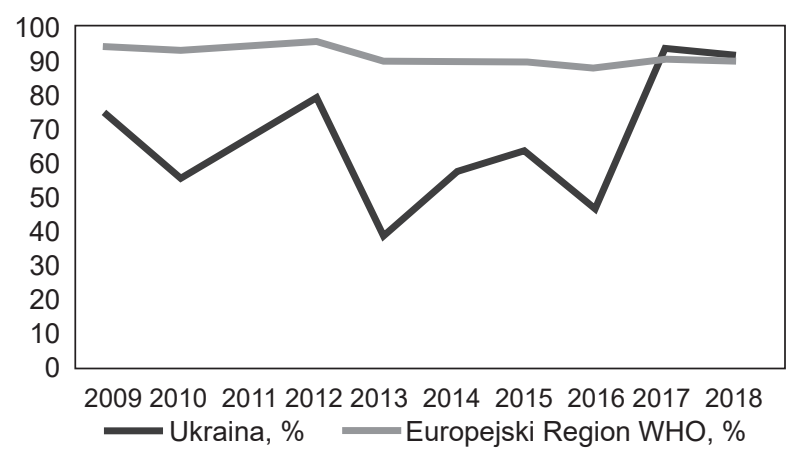

Wykres. 1. Zasięg szczepieniami profilaktycznymi przeciwko odrze dzieci do pierwszego roku życia na Ukrainie i w krajach Regionu Europejskiego WHO w latach 2009-2018.

Źródto: Opracowanie własne na podstawie danych Centrum Zdrowia Publicznego Ministerstwa Zdrowia Ukrainy, WHO

sugeruje, że niedopuszczalna liczba osób w tych kohortach urodzinowych pozostała podatna [20].

Najwyższą zapadalność odnotowano wśród dzieci z grupy wiekowej 5-9 lat (Wykres 2), w zachodnich obwodach kraju. Należy podkreślić, że przypadki choroby są rejestrowane we wszystkich obwodach (Tabela III).

$\mathrm{Na}$ Wykresie 2 można zaobserwować wspomnianą wyżej cykliczność. Pierwszy wzrost zachorowalności na odrę na Ukrainie był zarejestrowany w 2001, następny w 2005, potem w 2012 i 2018 roku. Eliminacja odry wymaga bardzo wysokiego poziomu odporności populacji. Grupy wiekowe dotknięte epidemią w latach 2005-2006 to te same grupy urodzeniowe, które były szczególnie dotknięte podczas epidemii odry w latach 2000-2001, co

\begin{tabular}{|c|c|c|c|c|c|c|c|c|c|c|c|c|}
\hline & \multicolumn{6}{|c|}{ Ukraina, \% } & \multicolumn{6}{|c|}{ Region Europejski WHO,\% } \\
\hline & :. & 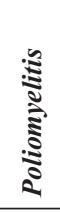 & 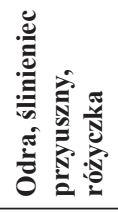 & 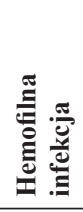 & 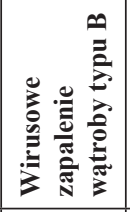 & 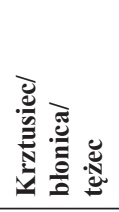 & 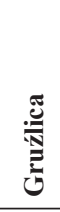 & 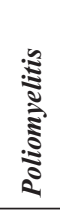 & 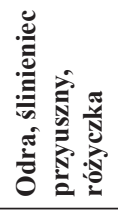 & 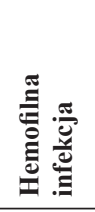 & 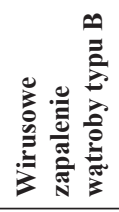 & 选 \\
\hline 2009 & 96 & 74 & 75 & 66 & 68 & 71 & 94 & 95 & 94 & 72 & 77 & 95 \\
\hline 2010 & 92 & 57 & 56 & 51 & 48 & 52 & 95 & 95 & 93 & 74 & 78 & 94 \\
\hline 2011 & 90 & 58 & 67 & 26 & 21 & 50 & 94 & 95 & 94 & 77 & 78 & 94 \\
\hline 2012 & 95 & 74 & 79 & 83 & 46 & 76 & 95 & 96 & 95 & 83 & 79 & 96 \\
\hline 2013 & 80 & 62 & 39 & 39 & 24 & 60 & 94 & 96 & 89 & 79 & 82 & 96 \\
\hline 2014 & 57 & 45 & 57 & 39 & 37 & 38 & 90 & 94 & 89 & 77 & 81 & 93 \\
\hline 2015 & 40 & 64 & 63 & 43 & 25 & 27 & 90 & 94 & 89 & 77 & 82 & 93 \\
\hline 2016 & 84 & 61 & 46 & 36 & 29 & 21 & 92 & 94 & 88 & 76 & 81 & 92 \\
\hline 2017 & 55 & 52 & 93 & 35 & 57 & 53 & 92 & 93 & 90 & 76 & 82 & 94 \\
\hline 2018 & 84 & 69 & 91 & 42 & 82 & 67 & \multicolumn{6}{|c|}{ brak danych } \\
\hline
\end{tabular}

Tabela I. Analiza porównawcza poziomu zasięgu szczepień profilaktycznych przeciwko odrze i innym chorobom dzieci poniżej pierwszego roku życia na Ukrainie i w krajach Regionu Europejskiego WHO w latach 2009-2018.

Źródło: Opracowanie własne na podstawie danych Centrum Zdrowia Publicznego Ministerstwa Zdrowia Ukrainy, WHO. 


\begin{tabular}{|c|c|c|c|}
\hline Rok & $\begin{array}{c}\text { Liczba przypadków } \\
\text { w jednym miesiącu (grudzień) }\end{array}$ & Liczba przypadków & $\begin{array}{c}\text { Zapadalność } \\
\text { na 100 tys. ludności }\end{array}$ \\
\hline 2016 & 24 & 90 & 0,24 \\
\hline 2017 & 1400 & 4782 & 11,23 \\
\hline 2018 & 10182 & 53219 & 125,47 \\
\hline
\end{tabular}

* Grudzień wybrano ze względu na sezonowość choroby.

Tabela II. Zachorowalność na odrę na Ukrainie (lata 2016-2018).

Źródło: Opracowanie własne na podstawie danych z Centrum Zdrowia Publicznego Ministerstwa Zdrowia Ukrainy, WHO.

\begin{tabular}{|c|c|c|c|c|c|}
\hline № & Obwód & $\begin{array}{c}\text { Liczba przypadków } \\
\text { odry }\end{array}$ & $\begin{array}{c}\text { Zapadalność } \\
\text { (na } 100 \text { tys. osób) }\end{array}$ & $\begin{array}{l}\text { Liczba przypadków } \\
\text { odry wśród dorosłych }\end{array}$ & $\begin{array}{c}\text { Liczba przypadków } \\
\text { odry wśród dzieci } \\
\text { (0-17 lat) }\end{array}$ \\
\hline 1 & Winnicki & 2948 & 187,07 & 1016 & 1932 \\
\hline 2 & Wołyński & 2074 & 199,71 & 653 & 1421 \\
\hline 3 & Dniepropietrowski & 980 & 30,33 & 471 & 509 \\
\hline 4 & Doniecki & 467 & 11,12 & 265 & 202 \\
\hline 5 & Żytomierski & 574 & 46,61 & 255 & 319 \\
\hline 6 & Zakarpacki & 4463 & 354,72 & 932 & 3531 \\
\hline 7 & Zaporoski & 365 & 21,18 & 225 & 140 \\
\hline 8 & Iwano-Frankowski & 5151 & 373,93 & 1371 & 3780 \\
\hline 9 & Kijowski & 1632 & 93,02 & 881 & 751 \\
\hline 10 & Kirowohradzki & 414 & 43,29 & 215 & 199 \\
\hline 11 & Ługański & 20 & 0,92 & 10 & 10 \\
\hline 12 & Lwowski & 10818 & 427,65 & 3037 & 7781 \\
\hline 13 & Mikołajowski & 1574 & 137,91 & 954 & 620 \\
\hline 14 & Odeski & 2737 & 114,85 & 1369 & 1368 \\
\hline 15 & Połtawski & 515 & 36,42 & 350 & 165 \\
\hline 16 & Rówieński & 2481 & 213,76 & 763 & 1718 \\
\hline 17 & Sumski & 302 & 27,59 & 205 & 97 \\
\hline 18 & Tarnopolski & 3279 & 311,59 & 1108 & 2171 \\
\hline 19 & Charkowski & 553 & 20,52 & 277 & 276 \\
\hline 20 & Chersoński & 253 & 24,16 & 192 & 61 \\
\hline 21 & Chmielnicki & 1198 & 94,00 & 536 & 662 \\
\hline 22 & Czerkaski & 330 & 27,04 & 212 & 118 \\
\hline 23 & Czerniowiecki & 2976 & 328,22 & 964 & 2012 \\
\hline 24 & Czernihowski & 525 & 51,47 & 310 & 215 \\
\hline 25 & Kijów & 2889 & 102,65 & 1726 & 1163 \\
\hline 26 & Ukraina & 49518 & 116,82 & 18297 & 31221 \\
\hline
\end{tabular}

Tabela III. Dane dotyczace zachorowalności na odrę wedtug stanu na 13 grudnia 2018 roku w ujęciu regionalnym.

Źródto: Opracowanie własne na podstawie danych z Ministerstwa Zdrowia Ukrainy; http://moz.gov.ua/article/news/operativni-dani-zahvorjuvanosti-na-kir-ta-analiz-zahvorjuvanosti-za-2018-rok (dostęp: 31.03.2019) [18].

sugeruje, że niedopuszczalna liczba osób w tych kohortach urodzinowych pozostała podatna [20].

W 2018 roku zapadalność na odrę była największa w zachodnich obwodach: zakarpackim, lwowskim, tarnopolskim i iwano-frankowskim (Tabela III), co bezpośrednio związano z najniższym poziomem wyszczepialności w tych obwodach (Rycina 1).

\section{Dzialanie profilaktyczne}

Odra jest chorobą zgłaszaną zgodnie z obowiązującymi przepisami. Pracownicy służby zdrowia powinni współpracować z lokalnymi partnerami, aby zaangażować pracowników służby zdrowia do wczesnego diagnozowania i zgłaszania przypadków choroby. 
Populacja (5-9 lat, zasięg: 57\%)

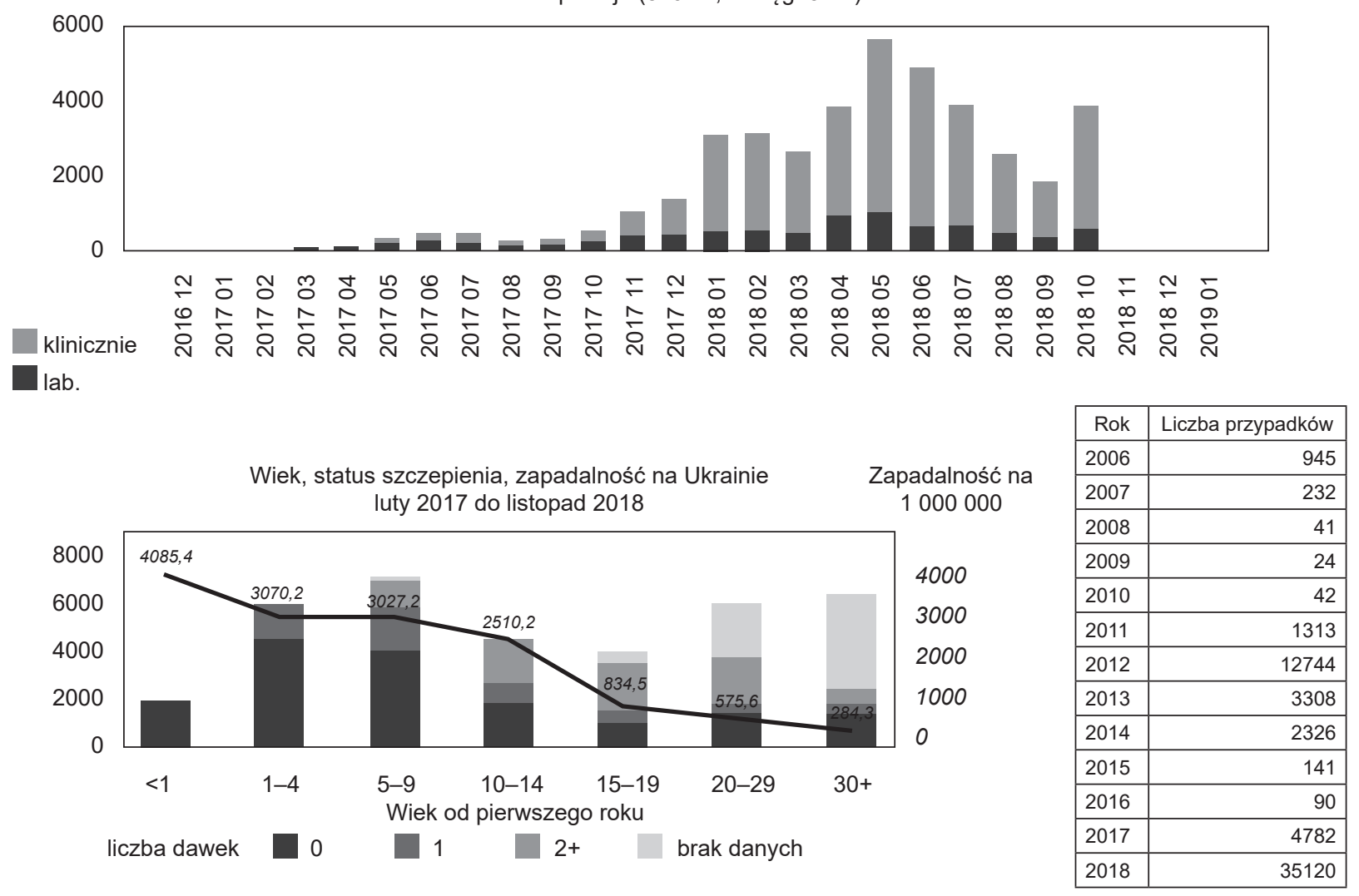

Wykres 2. Analiza porównawcza zarejestrowanych przypadków odry od 2006 do listopada 2018 roku na Ukrainie. Dynamika zmian liczby przypadków w różnych miesiacach 2017/2018.

Źródto: Światowa Organizacja Zdrowia (WHO), oficjalna strona internetowa: https://www.who.int/immunization/diseases/measles/ en/(dostęp: 20.12.2018) [3].

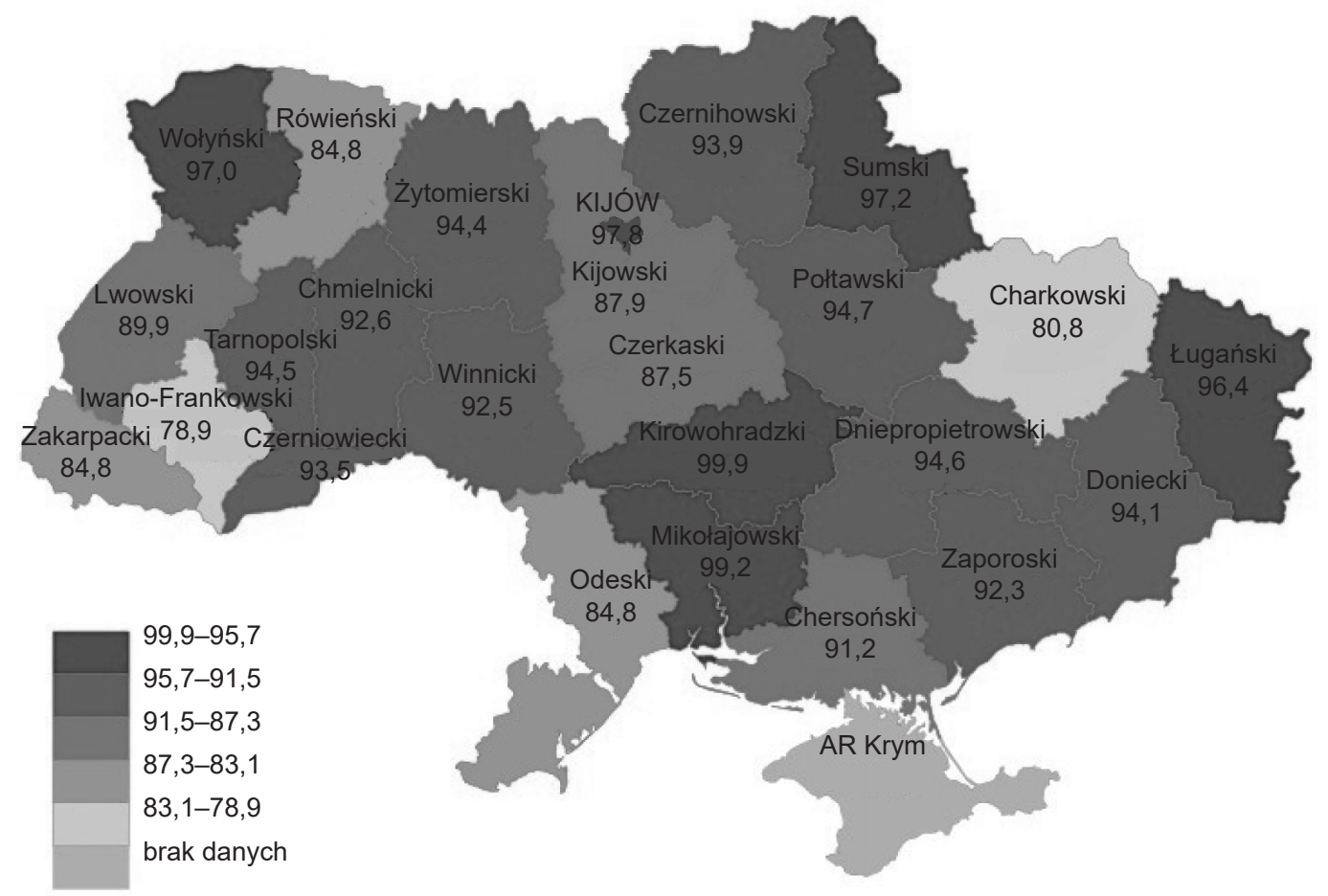

Rycina 1. Rozkład stosowania szczepień profilaktycznych dzieci poniżej pierszego roku życia w różnych obwodach Ukrainy. Źródto: Opracowanie własne na podstawie danych Centrum Zdrowia Publicznego Ministerstwa Zdrowia Ukrainy; https://phc.org. ua/pages/diseases/immunization/immunization-coverage (dostę: 12.12.2018) [19]. 
Od listopada 1994 roku na Ukrainie prowadzony jest wzmocniony nadzór, w tym potwierdzanie przypadków odry w sposób laboratoryjny przez badania śliny i krwi we wszystkich podejrzanych przypadkach oraz zapewnienie odpowiednich zestawów testowych, gwarantowane przez lokalne zespoły do spraw zdrowia. Próbki powinny być przetestowane na obecność przeciwciał IgM, IgG i RNA dla wirusa odry jak najszybciej po odebraniu krwi. Próbki wysyła się do Centralnego Departamentu Kontroli Wirusowej, gdzie są poddawane odpowiednim testom. Wyniki są zgłaszane lekarzowi rodzinnemu i lokalnym władzom do spraw zdrowia. Pracownicy Krajowej Grupy Szczepień monitorują potwierdzone przypadki w celu uzyskania dalszych informacji epidemiologicznych i klinicznych. Bierze się również pod uwagę historię otrzymania szczepionek przez osoby chore.

Zgodnie $\mathrm{z}$ aktualną wiedzą medyczną szczepienia są najskuteczniejszą metodą ochrony przed chorobami zakaźnymi. Wszystkie dzieci mają gwarantowane przez państwo prawo do szczepienia. Ze wszystkich badań wynika, że zastosowanie szczepień przeciwko chorobom zakaźnym pełni wielką rolę w poprawie stanu zdrowia we wszystkich krajach.

Zgodnie z Rozporządzeniem Ministra Zdrowia Ukrainy z dnia 9 września 2017 roku, Nr 1082 „O realizacji działań w zakresie immunizacji przeciwko odrze na Ukrainie" w 2017 roku zostały podjęte intensywne działania w zakresie immunizacji ukraińskiej populacji [21]. Jak widzimy w Tabeli I, zasięg szczepień dzieci do pierwszego roku życia jeszcze w 2016 roku wynosił 46\%, a po wprowadzeniu zintensyfikowanych działań zgodnych z powyższym rozporządzeniem zasięg ten wzrósł w 2017 roku dwukrotnie i wyniósł 93\%, a w 2018 - odpowiednio 91\%. Mimo wszystko wskaźnik zasięgu szczepień przeciwko odrze w populacji ukraińskiej wciąż pozostaje na poziomie niedostatecznym, czyli poniżej 95\%.

Ogromną rolę odgrywa informowanie pracowników szpitali o znaczeniu szczepień oraz podkreślanie ryzyka, na jakie narażeni są nieszczepieni pracownicy, a jednocześnie zwracanie uwagi na skuteczność i bezpieczeństwo szczepionek [22].

Z Ryciny 1 wynika, że najniższy stopień wyszczepienia występuje w obwodach zachodnich (lwowski - 89,9, iwano-frankowski - 78,9, zakarpacki, odeski i rówieński - 84,8 i charkowski - 80,8). Odpowiednio zachorowalność w tych regionach Ukrainy jest najwyższa.

Obecnie na Ukrainę dostarczane są szczepionki Priorix TM - lek produkowany przez GlaxoSmithKline Biologicals S.A. (Belgia). Jest to bezpieczna, skuteczna i wysokiej jakości szczepionka, zakwalifikowana przez WHO i najczęściej rekomendowana na świecie przez różne organizacje ochrony zdrowia. Ta i inne szczepionki zamieszczone $\mathrm{w}$ ukraińskim kalendarzu szczepień nabywane są przez Fundusz Organizacji Narodów Zjednoczonych do spraw Dzieci (UNICEF) na podstawie umowy z Ministerstwem Zdrowia Ukrainy. Środki pochodzą z budżetu państwa. Na 24 stycznia 2019 roku liczba dostępnych szczepionek MMR na Ukrainie wynosiła 1143174 dawek. Ministerstwo Zdrowia przekazuje zakupione szczepionki do departamentów ochrony zdro- wia $\mathrm{w}$ regionach, a te $\mathrm{z}$ kolei do państwowych zakładów opieki zdrowotnej, aby ukraińscy obywatele mogli otrzymać niezbędne szczepienia za darmo [18, 19].

Opierając się na aktualnych tendencjach w zakresie szczepień przeciwko odrze i częstości występowania, grupa ekspertów do spraw szczepień przeciwko odrze uznała, że eliminacja odry postępuje bardzo powoli, nie tak szybko, jak założono, a choroba występuje w wielu krajach, które wcześniej osiągnęły lub były bliskie uzyskania eliminacji. WHO nadal wzmacnia globalną sieć laboratoriów, aby zapewnić wczesną diagnozę odry i śledzić międzynarodowe rozprzestrzenianie się wirusów odry w celu umożliwienia bardziej skoordynowanego działania poszczególnych krajów w zakresie przeprowadzenia szczepień, a co za tym idzie zmniejszenia liczby zgonów z powodu odry [11].

\section{Dyskusja}

Zgodnie z danymi Centrum Zdrowia Publicznego Ukrainy większość chorych, u których stwierdzono odrę, nie zostało zaszczepionych lub podano im tylko jedną dawkę szczepionki. Taki bezpośredni związek obserwujemy, analizując niską wyszczepialność w regionach zachodnich Ukrainy i jednocześnie największą zapadalność w tych obwodach. Bez wątpienia można stwierdzić, iż zwiększenie liczby zachorowań na odrę na Ukrainie oraz $\mathrm{w}$ innych państwach jest związane z rosnącą grupą rodziców, którzy odmawiają szczepienia swoich dzieci, opierając się na różnego rodzaju mitach. Niektóre z takich mitów zostały opisane przez Magdalenę Kozelę i Michała Zabdyr-Jamroza z Collegium Medicum Uniwersytetu Jagiellońskiego w pracy zatytułowanej 6 mitów na temat szczepionek [23]. Jak stwierdzają autorzy, rozpowszechniane w ostatnich latach mity oparte są na całkowicie fałszywych, ale społecznie nośnych przesłankach, takich jak na przykład twierdzenia, że upowszechnianie się chorób cywilizacyjnych wynika z częstszego stosowania szczepień, szczepionki powodują autyzm, szczepienia są szkodliwe dla wcześniaków i inne. Są podstawy, by sądzić, że tego rodzaju mity są propagowane także przez ukraińskie ruchy antyszczepionkowe i stanowią jednocześnie treść bodźców motywujących ich działania.

Władze Ukrainy i eksperci z zakresu ochrony zdrowia otwarcie mówią o epidemii odry, a instytucje międzynarodowe (UNICEF) włączają się w akcje dostarczania na Ukrainę szczepionek. WHO nie pozostawia wątpliwości, że w Europie za gwałtowne zwiększenie liczby zachorowań na odrę odpowiada zbyt mała wyszczepialność. Nie bez powodu największy zasięg epidemii jest w tych krajach, w których - albo na skutek wieloletniej działalności ruchów anty-szczepionkowych (Włochy), albo z powodu trudnej sytuacji gospodarczej i powolnego reformowania systemu ochrony zdrowia (Ukraina) - szczepienia nie są realizowane w taki sposób, jak być powinny [2].

Pojawienie się epidemii odry na Ukrainie podkreśla jednak potrzebę ponownego podjęcia natychmiastowych działań zapobiegawczych i kontrolnych. Aby osiągnąć cel, jakim jest eliminacja odry, najważniejsze jest podniesienie świadomości wśród populacji ukraińskiej o tej cho- 
robie i zaangażowanie władz publicznych, które odpowiadają za tworzenie i realizację programów szczepień. Strategiczny plan Światowej Organizacji Zdrowia dotyczący eliminacji odry z regionu europejskiego przewiduje, że programy szczepień powinny osiągnąć i utrzymać minimum 95\% pokrycia dwiema dawkami szczepionki i być skierowane zarówno do osób w populacji ogólnej, jak i do jej wrażliwej grupy. Ponadto konieczna jest stała czujność, aby zapewnić, żeby podejrzane przypadki odry były niezwłocznie badane dla zidentyfikowania ognisk i wszczęcia działań kontrolnych prowadzących do ich ograniczenia.

\section{Wnioski}

1. Wyniki analizy aktualnego epidemiologicznego stanu zachorowań na odrę na Ukrainie wskazują na częste występowanie odry wśród populacji ukraińskiej w stosunku do populacji państw UE. Najwięcej zachorowań odnotowano u dzieci w grupie wiekowej 5-9 lat. Najwięcej przypadków występowania zachorowań zostało zarejestrowanych w zachodnich obwodach kraju (zakarpackim, lwowskim, tarnopolskim i iwano-frankowskim). Częstotliwość zachorowań jest tak duża, że możemy mówić o epidemii.

2. Na podstawie aktualnych tendencji w zakresie szczepień przeciwko odrze i częstotliwości jej występowania można jednoznacznie stwierdzić, że osiągnięcie ambitnego celu - eliminacji odry - jest w dużym stopniu zagrożone; sprzyjają temu zarówno migracja ludności, jak i bardzo szybko rozwijające się ruchy antyszczepionkowe, będące wynikiem poglądów opierających się na różnego rodzaju mitach.

3. Należy podkreślić, że zgodnie z aktualną wiedzą medyczną szczepienia są najskuteczniejszą metodą ochrony przed odrą. Zastosowanie szczepień ochronnych w danym przypadku ma pozytywne znaczenie nie tylko dla zaszczepionego, lecz także dla osób, które nie mogą być zaszczepione. Tworzy się wtedy immunitet populacyjny, co jest strategicznym celem w eliminacji odry dla każdego państwa.

\section{Przypis}

Regiony WHO: afrykański, amerykański, region Azji Południowo-Wschodniej, europejski, wschodni region śródziemnomorski, region Zachodniego Pacyfiku.

\section{Piśmiennictwo}

1. Effective aid, better health: Report prepared for the Accra High Level Forum on aid effectiveness, 2-4 September 2008, WHO; https://www.who.int/hdp/publications/en/ (dostęp: 20.02.2019).

2. Simons E., Ferrari M., Fricks J., Wannemuehler K., Anand A., Burton A., Strebel P., Assessment of the 2010 global measles mortality reduction goal: results from a model of surveillance data, „Lancet” 2012; 379: 2173-2178.

3. Oficjalna strona internetowa WHO; https://www.who.int/ immunization/diseases/measles/en/ (dostęp: 20.12.2018).
4. Magurano F., Baggieri M., Mazzilli F. at al., Measles in Italy: Viral strains and crossing borders, „International Journal of Infection Diseases" 2019; 79: 199-201.

5. Coroczny raport o stanie zdrowia ludności, sytuacji sanitarno-epidemiologicznej $i$ wynikach działalności systemu ochrony zdrowia Ukrainy, 2017 rok, red. W.W. Szafrański, Kijów 2018, s. 10.

6. Romaniuk P., Semigina T., Ukrainian health care system and its chances for successful transition from Soviet legacies, „Global Health” 2018; 14: 116.

7. Stepurko T., Semigina T., Health Index. Ukraine - 2017. Results of the national household survey, Kyiv 2018; http:// health-index.com.ua/zvit-index-2017-eng.pdf (dostęp: 25.03.2019).

8. World Health Organization (WHO), Global measles and rubella strategic plan: 2012-2020, WHO, Geneva 2012.

9. Moss W., Measles, „Lancet” 2017; 390: 2490-2502.

10. Bogusz J., Paradowska-Stankiewicz I., Measles in Poland in 2016, „Epidemiological Chronicle” 2018; 72 (3): 267-274.

11. Datta S.S, O'Connor P.M, Jankovic D., Muscat M., Ben Mamou M.C., Singh S., Kaloumenos T., Reef S., Papania M., Butler R., Progress and challenges in measles and rubella elimination in the WHO European Region, „Vaccine” 2018; 36: 5408-5415.

12. Durrheim D.N., Crowcroft N.S., Strebel P.M., Measles The epidemiology of elimination, „Vaccine” 2014; 32: 6880-6883.

13. Nowak-Starz G., Salwa A., Siwek M., Babiarz A., Zięba E., Zachorowania na odre - aktualny problem epidemiologiczny w Polsce i na świecie, „Zdrowie Publiczne Standardem Dobrostanu”, Rozdział XVI, 227-236.

14. Progress Toward Measles Elimination and CRS Prevention in Europe. February 8-10, 2015 Rome, Italy.

15. WHO Annual World Health Statistics Report, 2018; https://apps.who.int/iris/bitstream/handle/10665/272596/ 9789241565585-eng.pdf?ua=1 (dostęp: 12.02.2019).

16. Wadman M., Measles cases have tripled in Europe, fueled by Ukrainian outbreak, „Science” 2019, Feb. 12.

17. The United Nations, Ukraine Ukraine's efforts to stop measles outbreak continue as case total increases; http:// www.un.org.ua/en/information-centre/news/4275-ukraine-s-efforts-to-stop-measles-outbreak-continue-as-case-total-increases (dostęp: 31.03.2019).

18. Oficjalna strona internetowa Ministerstwa Zdrowia Ukrainy; http://moz.gov.ua/article/news/operativni-dani-zahvorjuvanosti-na-kir-ta-analiz-zahvorjuvanosti-za-2018-rok (dostęp: 31.03.2019).

19. Oficjalna strona internetowa Centrum Zdrowia Publicznego Ukrainy Ministerstwa Zdrowia Ukrainy; https://phc.org. ua/pages/diseases/other_social_diseases/measles (dostęp: 21.02.2019).

20. Velicko I., Müller L.L., Pebody R., Gergonne B., Aidyralieva C., Kostiuchenko N., Spika J.S., Nationwide measles epidemic in Ukraine: The effect of low vaccine effectiveness, „Vaccine” 2008; 26 (52): 6980-6985.

21. Rozporządzenie Ministra Zdrowia Ukrainy z dnia 9 września 2017 roku, Nr 1082 „O realizacji działań w zakresie immunizacji przeciwko odrze na Ukrainie”. 
22. Coppeta L., Pietroiusti A., Morucci L., Neri A., Ferarro M., Magrini A., Workplace vaccination against measles in a teaching hospital of Rome, „Journal of Hospital Infection” 2018; 101(3): 364-365.

23. Kozela M., Zabdyr-Jamróz M., 6 mitów na temat szczepionek, Blog Zdrowia Publicznego, Instytut Zdrowia Publicznego, Collegium Medicum Uniwersytet Jagielloński, Kraków, 16.11.2018; https://izp.wnz.cm.uj.edu.pl/pl/ blog/6-mitow-na-temat-szczepionek/ (dostęp: 10.01.2019). 